\title{
$\mathrm{P} 2 \mathrm{X} 7$ receptor activation leads to increased cell death in a radiosensitive human glioma cell line
}

\author{
Marina Petersen Gehring • \\ Talita Carneiro Brandão Pereira • \\ Rafael Fernandes Zanin • Magali Carvalho Borges • \\ Aroldo Braga Filho • Ana Maria Oliveira Battastini • \\ Maurício Reis Bogo • Guido Lenz • \\ Maria Martha Campos • Fernanda Bueno Morrone
}

Received: 9 January 2012 / Accepted: 2 May 2012 /Published online: 28 May 2012

(C) Springer Science+Business Media B.V. 2012

\begin{abstract}
Gliomas are the most lethal tumors of central nervous system. ATP is an important signaling molecule in CNS and it is a selective $\mathrm{P} 2 \mathrm{X} 7$ purinergic receptor ligand at high concentrations. Herein, we investigated whether the activation of P2X7R might be implicated in death of a radiosensitive human glioma lineage. The effects of P2X7R agonists (ATP and BzATP) and irradiation (2 Gy) on glioma cells were analyzed by MTT assay and annexinV/PI determination, whereas mRNA and protein P2X7R expression was assessed by qRT-PCR and flow cytometry, respectively. P2X7R pore formation was functionality examined by analyzing ethidium bromide uptake. The human glioma cells U-138 MG and U-251 MG were resistant to death when treated with either ATP $(5 \mathrm{mM})$ or BzATP $(100 \mu \mathrm{M})$, but the radiosensitive M059J glioma cells displayed a significant decrease of cell viability $(32.4 \pm 4.1 \%$
\end{abstract}

M. P. Gehring $•$ R. F. Zanin · F. B. Morrone $(\bowtie)$ Laboratório de Farmacologia Aplicada, PUCRS, Av. Ipiranga, 6681, Prédio 12C, Sala 148, Partenon, Porto Alegre, RS, Brazil 90619-900

e-mail: fbmorrone@gmail.com

T. C. B. Pereira $\cdot$ M. R. Bogo

Instituto Nacional de Ciência e Tecnologia Translacional em Medicina (INCT-TM), PUCRS,

Av. Ipiranga, 6681, Prédio 12C, Sala 172, Partenon,

Porto Alegre, RS, Brazil 90619-900

M. C. Borges · A. B. Filho

Serviço de Radioterapia, Hospital São Lucas, Av. Ipiranga, 6690, Azenha,

Porto Alegre, RS, Brazil 90160-090

A. M. O. Battastini

Departamento de Bioquímica, ICBS, UFRGS,

Rua Ramiro Barcelos, 2600-Anexo. Santa Cecília,

Porto Alegre, RS, Brazil 90035-000 and $25.6 \pm 3.3 \%$, respectively). The M059J lineage expresses significantly higher mRNA P2X7R levels when compared to the U-138 MG and U-251 cell lines $(0.40 \pm$ $0.00 ; 0.28 \pm 0.01$, and $0.31 \pm 0.01$, respectively), and irradiation upregulated $\mathrm{P} 2 \mathrm{X} 7 \mathrm{R}$ expression $(0.55 \pm 0.08)$ in this lineage. Noteworthy, P2X7R protein doubled after irradiation on M059J lineage, and increased in $50 \%$ and $42.6 \%$ when comparing M059J-irradiated to irradiated U-138 MG and U-251 MG cells, respectively. Ethidium bromide uptake was significantly increased in $104 \%$ and $77.8 \%$ when comparing M059J to U-138 MG and U-251MG, respectively. Finally, the selective P2X7R antagonist A740003 significantly decreased the cell death caused by irradiation. We provide novel evidence indicating that M059J human glioma cell line is ATP-P2X7R sensitive, pointing out the relevance of the purinergic P2X7R on glioma radiosensitivity.

\section{G. Lenz}

Laboratório de Sinalização e Plasticidade Celular, Departamento de Biofísica, Instituto de Biociências, UFRGS,

Av. Bento Gonçalves, 9500, Prédio 43431, Sala 107, Agronomia, Porto Alegre, RS, Brazil 91501-970

M. M. Campos

Instituto de Toxicologia e Farmacologia, PUCRS, Av. Ipiranga, 6681, Prédio 12C, Sala 101, Partenon, Porto Alegre, RS, Brazil 90619-900

T. C. B. Pereira $\cdot$ M. R. Bogo

Laboratório de Biologia Genômica e Molecular, PUCRS,

Av. Ipiranga, 6681, Prédio 12C, Sala 172, Partenon,

Porto Alegre, RS, Brazil 90160-090 
Keywords P2X7 receptor - Glioma - Irradiation · ATP . Radiosensitivity

\section{Introduction}

Glioblastoma multiforme (GBM) is the most aggressive type of all primary brain tumors, with an overall median survival of less than 1 year after diagnosis [1]. These tumors show a high proliferation rate, variability in tumor histopathology and diffusely infiltrate adjacent brain tissues, making surgical resection and radiotherapy limited [2]. Radiotherapy confers some survival advantages, but the resistance of the tumor cells to the effects of irradiation limits the treatment success [3].

Adenosine 5'-triphosphate (ATP) plays many important roles in the central nervous system (CNS), especially in modulating neurotransmission via two families of purinergic receptors, P2Y and P2X [4]. A peculiar member of the ionotropic $\mathrm{P} 2 \mathrm{X}$ receptor family is the $\mathrm{P} 2 \mathrm{X} 7$ receptor subtype (P2X7R). When this receptor is activated by ATP binding, it opens a pore through which molecules up to $900 \mathrm{Da}$ can pass. However, this pore opening requires prolonged exposure to ATP, and the full activation is reached only at millimolar ATP concentrations $[2,5]$. Some studies have reported that $\mathrm{P} 2 \mathrm{X} 7$ is responsible for ATP-induced cell death in various cell types through mechanisms involving necrotic features, such as swelling, loss of membrane integrity and also apoptotic features, such as shrinking and phosphatidylserine externalization $[2,6,7]$. Considering the internal concentration of ATP, which ranges from 5 to $10 \mathrm{mM}$ in most cells, cell death potentially elevates the extracellular concentrations of ATP to millimolar levels, similar to the concentrations that induce cell death in organotypic cultures [7].

The extracellular ATP present in the space around the brain tumors can be released by the excitotoxic death of the normal host cells around the tumor or at the moment of the surgical tumor resection [7]. Another extracellular source of ATP on brain tumors was recently shown: the $\gamma$-irradiation, which evokes ATP release and P2X7R activation [8]. Therefore, this study was aimed to investigate whether P2X7R is related to death of radiosensitive human glioma cell line. For this purpose, the effect of extracellular ATP was compared in human glioma cell lines U-138 MG and U-251 MG, which are radioresistant $[9,10]$ with the human glioma lineage M059J, sensitive to irradiation [3, 11, 12].

\section{Methods and materials}

Compounds

Adenosine 5'-triphosphate (ATP) and benzoyl adenosine 5'triphosphate (BzATP) were obtained from Santa Cruz
Biotechnology (Santa Cruz, CA, U.S.A); A740003 was obtained from Tocris (Ellisville, MO, USA); suramin was obtained from RBI (Natick, Mass., USA); reactive blue 2 (RB2), ethidium bromide was obtained from Sigma-Aldrich Co. (St. Louis, MO, USA) and anti-P2X7 receptor antibody was obtained from Alamone labs (Jerusalem, Israel).

Cell lines and cell culture

The U-138 MG, U-251 MG and M059J human glioblastoma cell lines were obtained from American Type Culture Collection (ATCC - Rockville, Maryland, USA). Cells were cultured in Dulbecco's Modified Eagle Medium (DMEM) with $15 \%$ fetal bovine serum (FBS) at a temperature of $37^{\circ}$ $\mathrm{C}$, a minimum relative humidity of $95 \%$, and an atmosphere of $5 \% \mathrm{CO}_{2}$ in air.

Cell viability

Glioma cells were seeded at $7 \times 10^{3}$ cells per well in 96 -well plates and grown for $24 \mathrm{~h}$. The cells were treated with ATP $(0.5,3$, and $5 \mathrm{mM})$ or with BzATP $(100 \mu \mathrm{M})$. M059J cells were pre-treated with the selective $\mathrm{P} 2 \mathrm{X} 7 \mathrm{R}$ antagonist A740003 $(10 \mu \mathrm{M})$ [13-18] or with the two non-selective P2 receptor antagonists suramin $(30 \mu \mathrm{M})$ or RB2 $(100 \mu \mathrm{M})$, and after 20 min with ATP $(5 \mathrm{mM})$ for $24 \mathrm{~h}$. At the end of this period, the medium was removed, the cells were washed with calcium magnesium-free medium (CMF) and $100 \mu \mathrm{l}$ of 3-(4,5-dimethylthiazol-2-yl)-2,5-diphenyltetrazolium bromide solution (MTT) (MTT $5 \mathrm{mg} / \mathrm{ml}$ in PBS in $90 \%$ DMEM $/ 10 \% \mathrm{FBS}$ ) was added to the cells and incubated for $3 \mathrm{~h}$. The formazan crystals were dissolved with $100 \mu \mathrm{l}$ of dimethyl sulfoxide (DMSO). The absorbance was quantified in 96-well plates (Spectra Max M2e, Molecular Devices) at $595 \mathrm{~nm}$. This absorbance was linearly proportional to the number of live cells with active mitochondria. The cell viability was calculated using Eq.:

Cell viability $(\%)=\left(\mathrm{Abs}_{\mathrm{s}} / \mathrm{Abs}_{\text {control }}\right) 100$

where $\mathrm{Abs}_{\mathrm{s}}$ is the absorbance of cells treated with different formulations and $\mathrm{Abs}_{\text {control }}$ is the absorbance of control cells (incubated with cell culture medium only).

Gamma irradiation

The cells were gamma irradiated at a 2 Gy dose using a Cobalt Theretron Phoenix (Philips, Eindhoven, The Netherlands) at a source-to-target distance of $70 \mathrm{~cm}$ [12]. All irradiation experiments were performed with confluent cells kept in cell culture medium [11]. The treatments were performed on the same day of irradiation. Irradiation was undertaken at the Radiotherapy Service, Hospital São 
Lucas, Pontifícia Universidade Católica do Rio Grande do Sul (PUCRS).

\section{Cell counting}

Glioma cells were seeded at $18 \times 10^{3}$ cells per well in 24well plates. On the second day, the cells were treated with ATP ( $5 \mathrm{mM}$ ) or irradiation (2 Gy). The M059J cells were cotreated with the selective P2X7R antagonist A740003 $(10 \mu \mathrm{M})$ and then irradiated. After $24 \mathrm{~h}$, the medium was collected and $200 \mu \mathrm{l}$ of trypsin/EDTA solution was added to detach the cells, which were counted in hemocytometer. The cell number of the control group (not treated cells) was considered $100 \%$.

\section{Analysis of mRNA expression}

Glioma cells were seeded at $2 \times 10^{5}$ cells per well in 6well plates and grown for $24 \mathrm{~h}$. The cells were irradiated ( 2 Gy), control cells were not irradiated; after $24 \mathrm{~h}$ the total RNA was isolated with Trizol LS reagent (Invitrogen, Carlsbad, California, USA) in accordance with the manufacturer's instructions. The total RNA was quantified by spectrophotometry and the cDNA was synthesized with ImProm-II ${ }^{\mathrm{TM}}$ Reverse Transcription System (Promega) from $1 \mu \mathrm{g}$ total RNA, in accordance with the manufacturer's instructions. Quantitative PCR was performed using SYBR Green I (Invitrogen) to detect double-strand cDNA synthesis. Reactions were done in a volume of $25 \mu \mathrm{L}$ using $12.5 \mu \mathrm{L}$ of diluted cDNA (1:50), containing a final concentration of $0.2 \times$ SYBR Green I (Invitrogen), $100 \mu \mathrm{M}$ dNTP, $1 \times$ PCR Buffer, $3 \mathrm{mM} \mathrm{MgCl} 2,0.25 \mathrm{U}$ Platinum Taq DNA Polymerase (Invitrogen) and $200 \mathrm{nM}$ of each reverse and forward primers (Table 1) [19, 20]. The PCR cycling conditions were: an initial polymerase activation step for $5 \mathrm{~min}$ at $94{ }^{\circ} \mathrm{C}, 40$ cycles of $15 \mathrm{~s}$ at $94{ }^{\circ} \mathrm{C}$ for denaturation, $10 \mathrm{~s}$ at $60{ }^{\circ} \mathrm{C}$ for annealing and $15 \mathrm{~s}$ at $72{ }^{\circ} \mathrm{C}$ for elongation. At the end of cycling protocol, a melting-curve analysis was included and fluorescence measured from $60{ }^{\circ} \mathrm{C}$ to $99{ }^{\circ} \mathrm{C}$. Relative expression levels were determined with 7500 Fast RealTime System Sequence Detection Software v.2.0.5 (Applied Biosystems). The efficiency per sample was calculated using LinRegPCR 11.0 Software (http:// LinRegPCR.nl). Relative RNA expression levels were determined using the $2^{-\Delta \Delta C T}$ method. The stability of the references genes $18 \mathrm{~S}, \beta$-actin, B2M, GAPDH $(M$ value) and the optimal number of reference genes according to the pairwise variation $(V)$ were analyzed by $\mathrm{GeN}$ orm 3.5 Software (http://medgen.ugent.be/genorm/).

\section{P2X7R protein flow cytometry analysis}

The expression of $\mathrm{P} 2 \mathrm{X} 7 \mathrm{R}$ protein on human glioma cells lines (U-138 MG, U-251 MG, and M059J) was evaluated by flow cytometry, using the following antibody $(\mathrm{Ab})$ : rabbit polyclonal anti-mouse P2X7R (APR004; Alomone Labs, Jerusalem, Israel). Briefly, before staining, the cells were fixed in Cytofix Buffer I (BD Biosciences) for $10 \mathrm{~min}$ at $37^{\circ} \mathrm{C}$. After washing, permeabilization was done with Perm Buffer III (BD Biosciences) for $30 \mathrm{~min}$ on ice. Then, glioma cells were washed and incubated for $30 \mathrm{~min}$ with the above primary antibody. Finally, after washing, cells were stained with secondary FITC-conjugated goat antirabbit $\operatorname{IgG~} \mathrm{Ab}$ (Invitrogen) for $30 \mathrm{~min}$ on ice. Cell fluorescence was measured with FACSCantoII Flow Cytometer (BD Biosciences).

Ethidium bromide uptake

P2X7R pore formation was functionality examined in human glioma cell lines (U-138 MG, U-251 MG, and M059J) by analyzing ethidium bromide uptake using FACSCanto II Flow Cytometer (BD Biosciences). For this experiment, we used two flasks of $25 \mathrm{~cm}^{2}$ for each lineage: one flask was irradiated at $2 \mathrm{~Gy}$, whilst the other one served as the nonirradiated control. The adhered glioma cells were
Table 1 Human primer sequences

\begin{tabular}{lllll}
\hline Gene & & Primers $\left(5^{\prime}-3^{\prime}\right)$ & Amplicon size (bp) & GenBank ID \\
\hline$\beta$-actin $^{\mathrm{a}}$ & $\mathrm{F}$ & CATCGAGCACGGCATCGTCA & 211 & NM_001101 \\
& $\mathrm{R}$ & TAGCACAGCCTGGATAGCAAC & & NR_003286 \\
$18 \mathrm{~s}^{\mathrm{a}}$ & $\mathrm{F}$ & GTAACCCGTTGAACCCCATT & 151 & \\
& $\mathrm{R}$ & CCATCCAATCGGTAGTAGCG & & NM_004048 \\
$\mathrm{B}^{\mathrm{a}} \mathrm{M}^{\mathrm{a}}$ & $\mathrm{F}$ & ACTGAATTCACCCCCACTG & 114 & NM_002046 \\
& $\mathrm{R}$ & CCTCCATGATGCTGCTTACA & & \\
GAPDH $^{\mathrm{a}}$ & $\mathrm{F}$ & TGCACCACCAACTGCTTA & 177 & NM_002562 \\
& $\mathrm{R}$ & GGATGCAGGGATGATGTTC & & \\
\hline
\end{tabular}


trypsinized (trypsin/EDTA solution) to detach the cells and centrifuged for $10 \mathrm{~min}, 1600 \mathrm{RPM}$ at $4{ }^{\circ} \mathrm{C}$. Glioma cells were resuspended in DMEM in order to have $2 \times 10^{5}$ cells/ sample $(200 \mu \mathrm{l}$ each sample). Cells were distributed in cytometry tubes and incubated at $37{ }^{\circ} \mathrm{C}$ for $5 \mathrm{~min}$. At the end of this period, cells were treated with ATP $(5 \mathrm{mM})$ or ATP $(5 \mathrm{mM})$ plus A740003 $(10 \mu \mathrm{M})$ (both irradiated and non-irradiated groups of cells) for $5 \mathrm{~min}$. After this time, ethidium bromide was added to cytometry tubes $(2.5 \mathrm{mg} / \mathrm{ml})$ for additional $5 \mathrm{~min}$. Immediately, pore functionality experiment was performed and the results were analyzed using FlowJo Software (Tree Star).

\section{Annexin V/PI flow cytometry staining technique}

M059J glioma cells were seeded at $2 \times 10^{5}$ cells per well in 6 -well plates and grown for $24 \mathrm{~h}$. The cells were treated with P2X7R agonist, antagonist, or/and irradiation for $24 \mathrm{~h}$. Dead cells were quantified by annexin V-FITC-propidium iodide (PI) double staining, using Annexin V-FITC Apoptosis Detection Kit I (BD Biosciences) $24 \mathrm{~h}$ after treatment, according to the manufacturer's instructions. Experiments were performed on FACSCanto II Flow Cytometer (BD Biosciences) and the results were analyzed using FlowJo Software (Tree Star).

\section{Statistical analysis}

The number of experimental replications is given in the figure legends; replicate experiments were conducted with cultures from different seeding procedures. Data was analyzed by one-way analysis of variance (ANOVA) followed by Tukey's post-hoc test, or by Student's $t$ test using GraphPad Software (San Diego, CA, U.S.A.). $P$ values $<0.05$ were taken to indicate statistical significance.

\section{Results}

\section{Cell viability}

In this study, we tested the effect of irradiation and purinergic ligands in different glioma cell lines. Cell viability was not altered when the human glioma cell lines U-138 MG and U-251 MG were treated with either ATP $(5 \mathrm{mM})$ or BzATP $(100 \mu \mathrm{M})($ Fig. 1a-b). Otherwise, the treatment with a high ATP concentration $(5 \mathrm{mM})$ or the selective P2X7R agonist BzATP $(100 \mu \mathrm{M})$ significantly diminished the cell viability (32.4 $\pm 4.1 \%$ and $25.6 \pm 3.3 \%$, respectively) of M059J glioma cell line (Fig. 1c). The ATP resistance of U-138 MG lineage has been already described by our group [7], and a similar pattern of resistance was observed in this study with
U-251 MG cells, contrasting with ATP sensitivity exhibited by the M059J cell line.

Next, we investigated whether ATP-induced cytotoxicity in M059J cell line might be related to the activation of P2X7R. As shown in the Fig. 1d, the selective P2X7R antagonist A740003 partially prevented the cytotoxicity caused by ATP $5 \mathrm{mM}$ (from $32.4 \%$ to $19.6 \%$ ), indicating that this receptor is probably implicated in the cytotoxic effects displayed by ATP. However, both non-specific P2 receptor antagonists (suramin and RB2) failed to reverse the effects of ATP. Indeed, the treatment with suramin $(30 \mu \mathrm{M})$ plus ATP $(5 \mathrm{mM})$ significantly reduced the cell viability $(61.1 \pm 2.77 \%)$ when compared to the treatment with ATP (5 mM) alone (Fig. 1d). As previously described in another study from our group, ATP added at the beginning of the treatment gets slowly degraded and is almost absent in the conditioned medium after $24 \mathrm{~h}$. In this way, during the timecourse of the experiment, cells experience a mixed concentration of the degradation products of ATP [21]. Once these extracellular nucleotides can induce cell proliferation in human glioma cell lines [21-23], we believe that some of the $\mathrm{P} 2$ receptor antagonized by suramin and RB2 maintain the survival of glioma cells, when activated by extracellular nucleotides via P2 purinoreceptors [22]. Thus, blocking some specific purinergic receptors that sustain glioma cells proliferation could lead to an increase of glioma cell death, as shown in Fig. 1d.

\section{Cell counting}

As shown in Fig. 2a-b, the treatment with ATP $(5 \mathrm{mM})$, irradiation at 2 Gy or irradiation plus ATP $(5 \mathrm{mM})$ did not affect the U-138 MG and U-251 MG glioma cell numbers, which indicate an absence of effect on cell proliferation. Interestingly, these same treatments led to significant reductions in the percentage of cell number of the M059J cell line (Fig. 2c), $44.6 \pm 5.3 \%$ for ATP $(5 \mathrm{mM}), 24.0 \pm 3.6 \%$ for irradiation and $69.2 \pm 9.2 \%$ for irradiation plus ATP treatment. This data supports that M059J cells are radiosensitive and ATP sensitive, whereas U-138 MG and U-251 MG cell lines are radioresistant [3, 9-12]. These results are in agreement with the data presented in Fig. 1 demonstrating that human glioma cell line M059J is more sensitive to high ATP concentration than U-138 MG and U251-MG human glioma cell lines. Noteworthy, co-treatment with irradiation plus ATP $(5 \mathrm{mM})$ increased the reduction of cell counting on glioma cell line M059J (Fig. 2c), in comparison to irradiation only, indicating that ATP has an additional effect on cell depletion induced by the irradiation on radiosensitive glioma cells.

To determine if P2X7R might be related to the radiosensitivity of the M059J cells, this lineage was co-treated with the selective P2X7R antagonist A740003 $(10 \mu \mathrm{M})$ and then 
a) U-138 MG

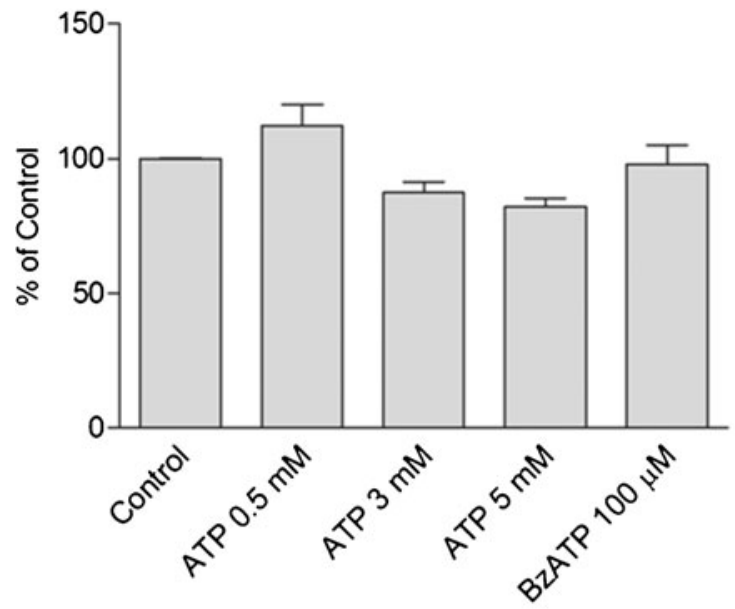

c) M059J

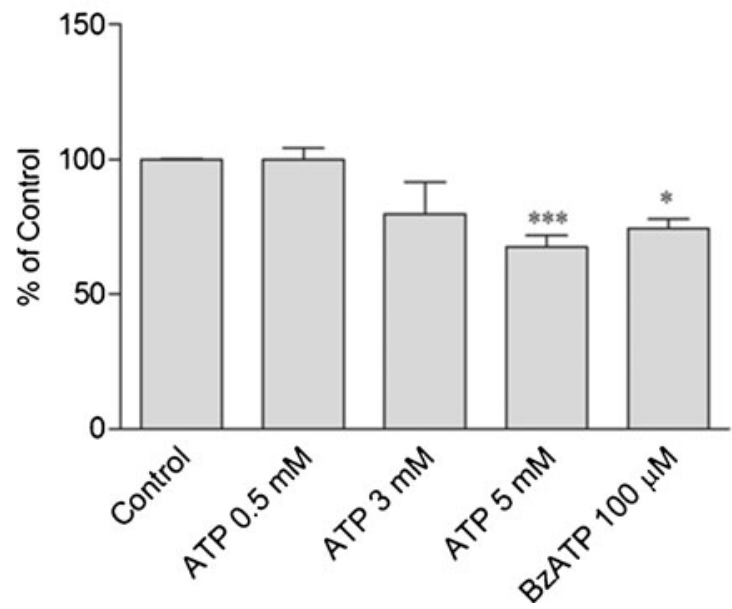

Fig. 1 a-c Effect of treatment with $\operatorname{ATP}(0.5,3$, and $5 \mathrm{mM})$ and BzATP $(100 \mu \mathrm{M})$ on cell viability of human glioma lines after $24 \mathrm{~h}$. d Effects of pre-treatment with the selective P2X7R antagonist A740003 $(10 \mu \mathrm{M})$ or P2R suramin $(30 \mu \mathrm{M})$ or P2YR RB2 $(100 \mu \mathrm{M})$ antagonists and ATP $(5 \mathrm{mM})$ on cell viability of M059J cells after $24 \mathrm{~h}$.

irradiated (2 Gy). As shown in Fig. 2c, A740003 completely reversed the cell number decrease caused by irradiation (2 Gy) (from $76.0 \pm 3.62 \%$ of cells to $105.3 \pm 1.79 \%$ ), clearly indicating that P2X7R is involved in the radiosensitivity of M059J human glioma cells. As described before, the irradiation induces ATP release [8], wherefore the selective $\mathrm{P} 2 \mathrm{X} 7$ receptor antagonist A740003 probably blocks the effect of nucleotides released by irradiation. It is important to note that, although it appears that treatment with A740003 has not completely blocked the ATP effects, there was no significant difference between the two groups: A740003 + ATP and A740003+irradiation. Finally, we treated the cells with A740003 $(10 \mu \mathrm{M})$ plus irradiation plus ATP $(5 \mathrm{mM})$. Data shows that the cell number reduction was not significantly different when compared to the control group.

\section{b) U-251 MG}

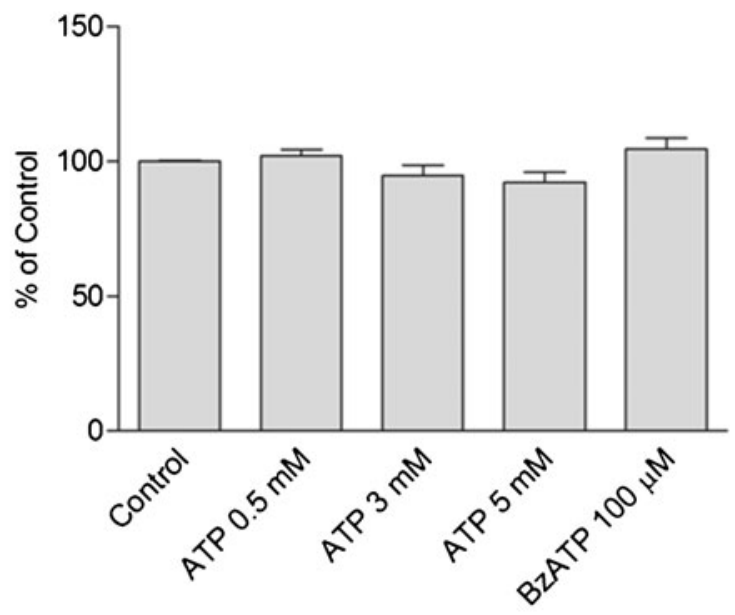

d) M059J

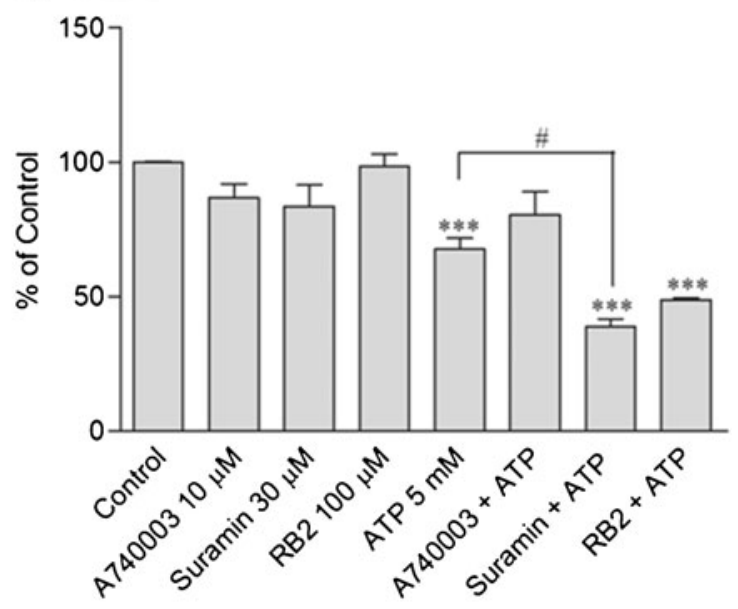

The experiments were carried out at least three times in triplicate. Each column represents the mean \pm SEM. $* p<0.05 ; * * * p<0.001$ for comparison versus control and $\# p<0.05$ for comparison from the respective group, as determined by ANOVA/Tukey-Kramer test

\section{Analysis of mRNA expression}

To determine the reference genes to be used in the present study, we analyzed the stability of $\beta$-actin, $18 \mathrm{~S}, \mathrm{~B} 2 \mathrm{M}$, and GAPDH based on previous reports of housekeeping genes [19]. The most stable reference genes were $18 \mathrm{~S}, \mathrm{~B} 2 \mathrm{M}$, and GAPDH, whereas $\beta$-actin was the less stable. We also analyzed the optimal number of internal control genes for normalization with geNorm. The results indicated the combination of the three or four most stable genes for normalization purposes. As $\beta$-actin gene was found very unstable, we chose to use the other three constitutive genes for normalization (data not shown).

The expression of P2X7R in U-138 MG, U-251 MG, and M059J cells exposed to control (standard cell culture medium alone) was analyzed and representative results are 


\section{a) U-138 MG}

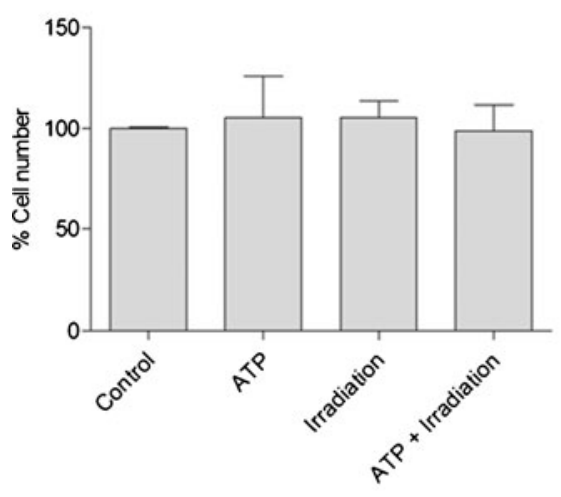

b) U-251 MG

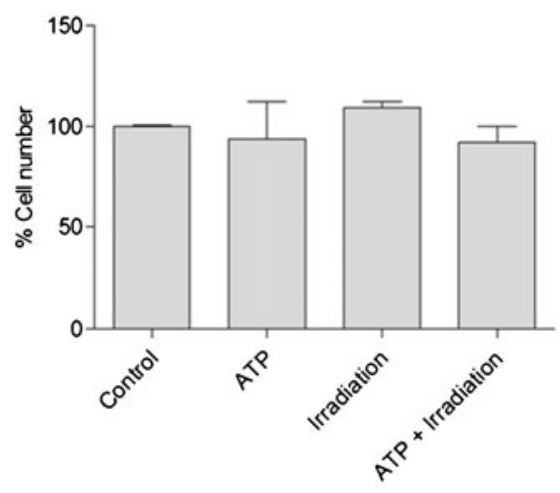

c) $\mathrm{M059 \textrm {J }}$

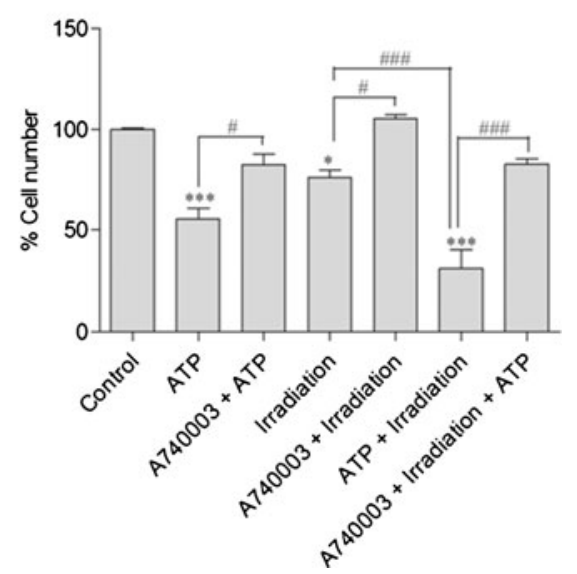

Fig. 2 a-c Effect of treatment with ATP $5 \mathrm{mM}$, irradiation (2 Gy), or ATP and irradiation on cell number of human glioma cells, which was also co-treated with A740003 $(10 \mu \mathrm{M})$ and irradiation. The cell number of the control group (not treated cells) was considered $100 \%$. The

presented in Fig. 3a. The M059J lineage expressed significantly higher P2X7R levels when compared to U-138 MG and U-251 MG cell lines $(0.40 \pm 0.00,0.28 \pm 0.01$, and $0.31 \pm$ 0.01 , respectively). As shown in Fig. 3b, the treatment with irradiation (2 Gy) caused a marked increase in P2X7R expression in M059J cells, in comparison to M059J nonirradiated control cells $(37.5 \%$, from $0.40 \pm 0.00$ to $0.55 \pm$ 0.08 ), what probably turns M059J cells more sensitive to the released ATP induced by irradiation [8].

\section{P2X7R protein flow cytometry analysis}

We investigated P2X7R protein levels of U-138 MG, U-251 $\mathrm{MG}$, and M059J cells. All human non-irradiated glioma cell lines did not present any difference in the P2X7R protein

a)

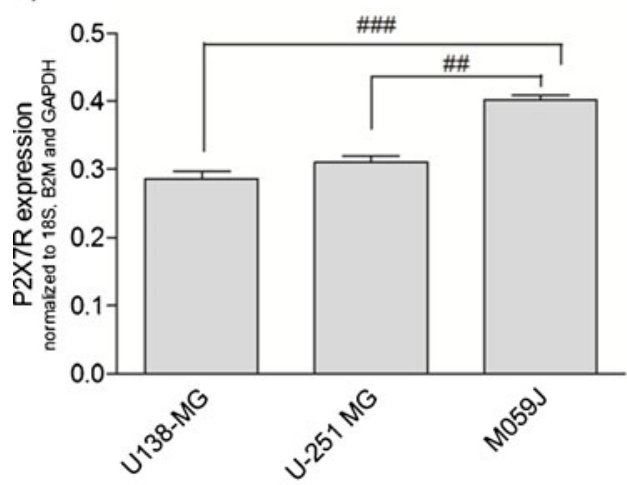

Fig. 3 a Relative gene expression profile of $\mathrm{P} 2 \mathrm{X} 7 \mathrm{R}$ on human glioma cell lines. b Effect of irradiation (2 Gy) on P2X7R expression on M059J human glioma cell line. Overall results from $N=4$ independent experiments. Each column represents the mean \pm SEM. $* * * p<0.001$ for experiment was carried out at least three times in triplicate. Each column represents the mean \pm SEM. ${ }^{*} p<0.05$; ${ }^{* * *} p<0.001$ for comparison versus control and $\# p<0.05$; \#\#\#p $<0.001$ for comparison from the respective group, as determined by ANOVA with Tukey's post-hoc test

level (Fig. 4a-c, dotted lines). The irradiation treatment (2 Gy) induced visible difference in P2X7R protein expression in the lineages analyzed. As shown in Fig. 4a-c (black line), cell lineages tested showed an increased P2X7R protein level after irradiation when compared to non-irradiated cells (dotted line). M059J lineage doubled P2X7R protein after irradiation, in relation to non-irradiated M059 cells

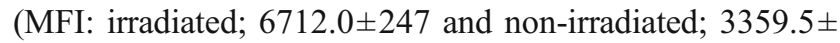
159.5) (Fig. 4c), and was found significantly increased when compared to the irradiated U-138 MG and U-251 MG cell lines (MFI, $4446.5 \pm 178.5$ and $4704.5 \pm 183.5$, respectively) (Fig. 4a, b). The increased levels of P2X7R protein observed in M059J cells after irradiation indicates that this receptor could potentially be involved in the death induced by irradiation of radiosensitive cells.

\section{b) M059J}

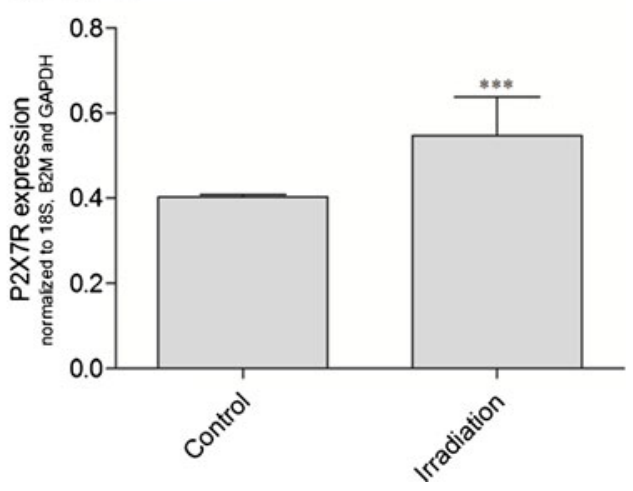

comparison versus control, as determined by Student's $t$ test and \#\#p< 0.01 , \#\#\#p $<0.001$ for comparison from the respective group, as determined by ANOVA with Tukey's post-hoc test 


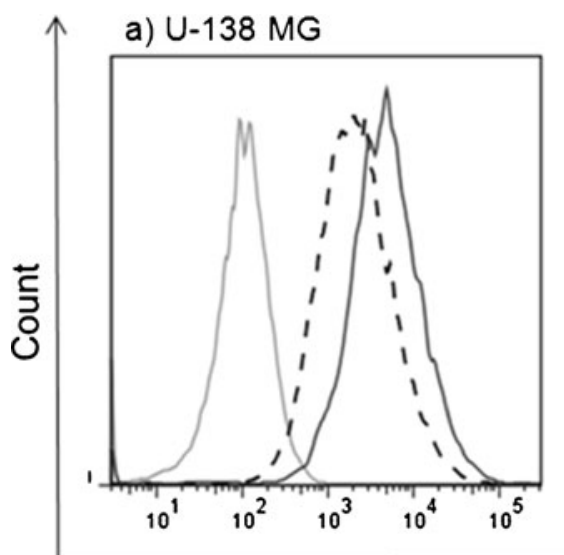

d)

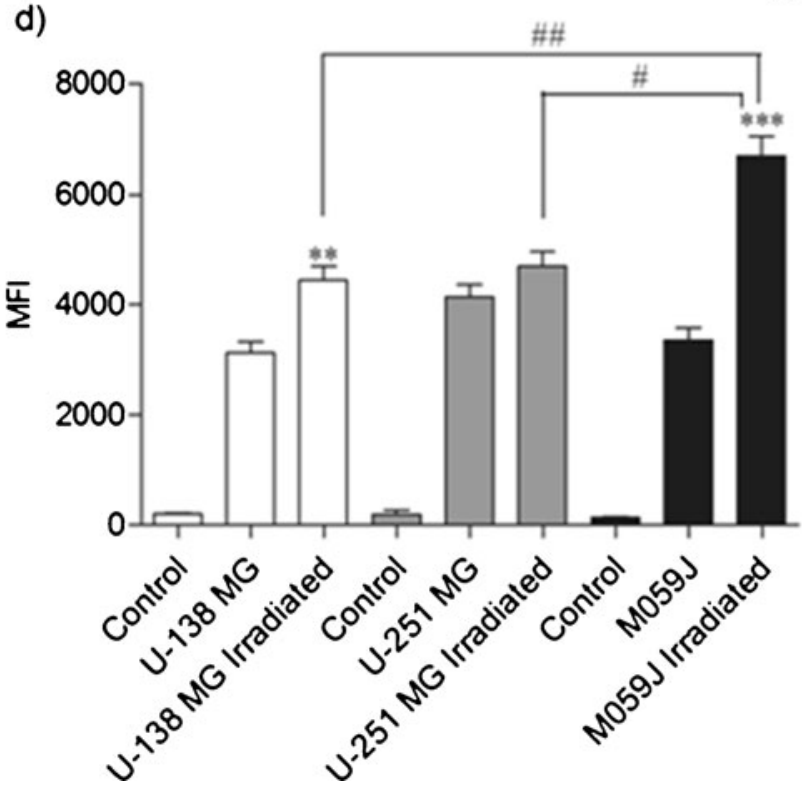

Fig. 4 a-c Representative histogram of P2X7R protein levels on human glioma cell lines. Gray line: secondary antibody control; dotted line: non-irradiated cells and black line: irradiated cells. Data shown is representative of at least two independent experiments. d Mean fluorescence intensity (MFI) for P2X7R. Each column represents the mean

\section{Ethidium bromide uptake}

In order to investigate whether P2X7R expressed is functional as a pore on glioma cell lines, before and after irradiation treatment ( $2 \mathrm{~Gy})$, we stimulated non-irradiated and irradiated cells with ATP $(5 \mathrm{mM})$ and analyzed the ethidium bromide uptake. The results demonstrated a significant difference in ethidium bromide uptake capacity among the non-irradiated lineages. As shown in Fig. 5a, the M059J cells (black line) showed a significant higher capacity of ethidium bromide uptake, when compared to U-138 MG (gray line) and U-251 MG (dotted line) (MFI 4763.5 \pm $198.5,1364.0 \pm 102$, and $3001.5 \pm 42.5$ ), what is probably related to its ATP-P2X7R sensitivity. c) M059J

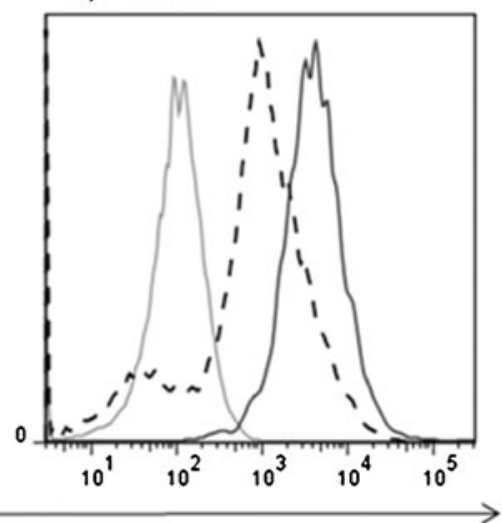

2X7R protein

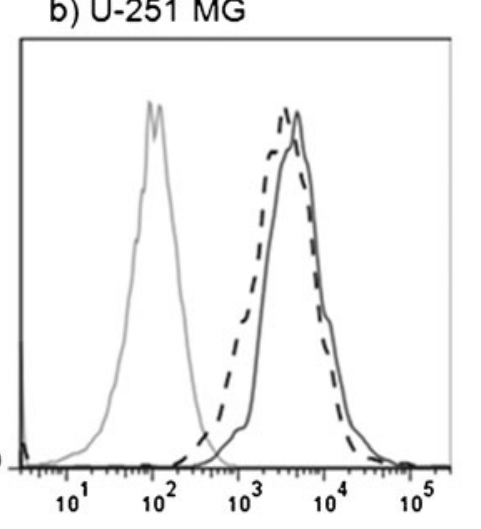


Fig. 5 Representative histogram of ethidium bromide uptake after stimulus with ATP $(5 \mathrm{mM})$ on a non-irradiated cells or b irradiated cells. Gray line: U-138 MG; dotted line: U$251 \mathrm{MG}$ and black line: M059J. c Mean fluorescence intensity (MFI) for ethidium bromide uptake after stimulus with ATP $(5 \mathrm{mM})$ on non-irradiated and irradiated human glioma cell lines. Data shown is representative of at least two independent experiments. Each column represents the mean \pm SEM. ${ }^{*} p<$ 0.05 for comparison between M059J non-irradiated versus M059J irradiated cells and \#\#p $<0.01$, \#\#\#p<0.001 for comparison from the same treatment between lineages, as determined by ANOVA with Tukey's post-hoc test

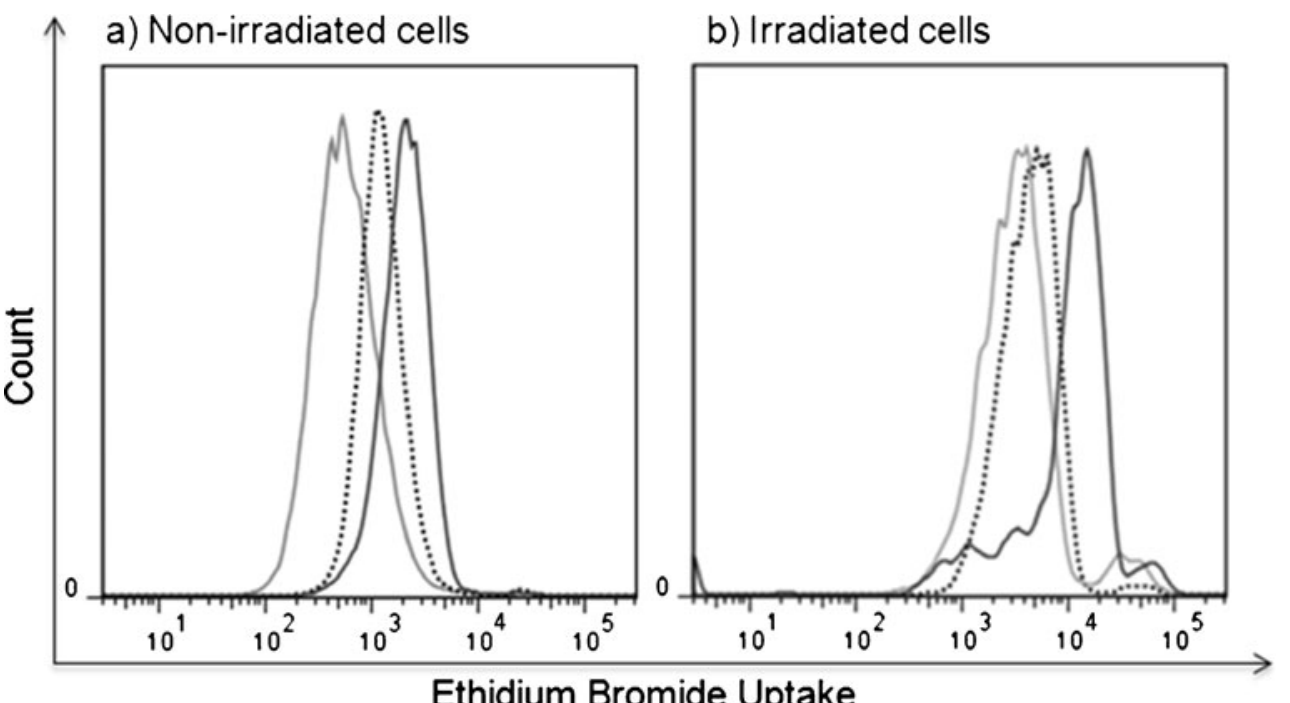

c)

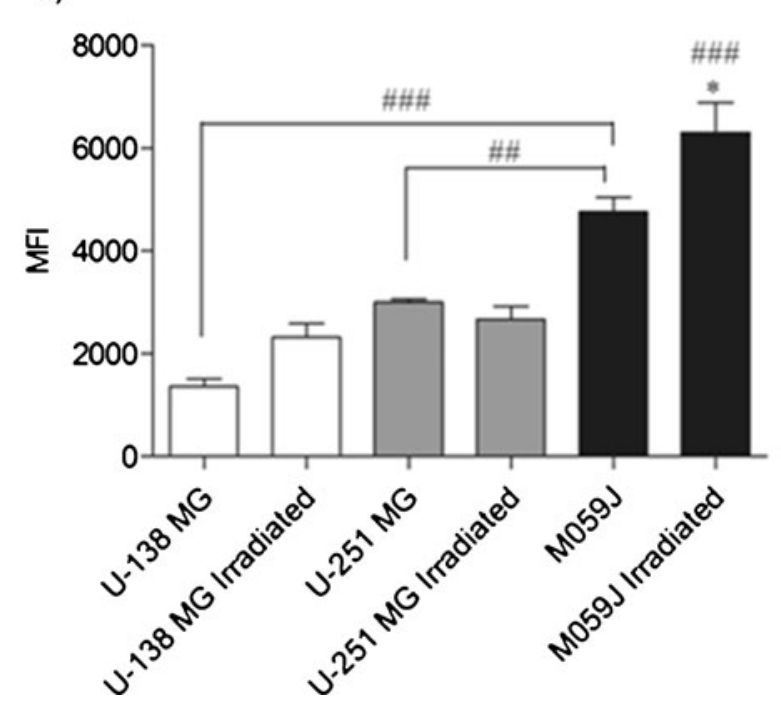

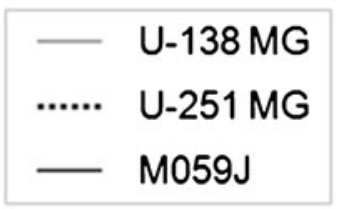

less mRNA P2X7R (Fig. 3a) and also present less P2X7R protein levels after irradiation (Fig. 4), when compared to the M059J cell line. We might suppose that these radioresistant cell lines developed a mutation of any component of P2X7Rinduced cell death system, compromising the irradiationinduced P2X7R protein and activity increase (Fig. 5b).

To verify that ethidium bromide uptake was induced by ATP via P2X7R pore on human glioma cell lines, we blocked these cells with the P2X7R selective antagonist A740003 $(10 \mu \mathrm{M}) 20 \mathrm{~min}$ before ATP treatment (on irradiated and non-irradiated cells), which caused a reduction in ethidium bromide uptake (data not shown), confirming that the increase in ethidium bromide uptake observed after ATP (5 mM) treatment was via P2X7R.

\section{Annexin V/PI flow cytometric staining technique}

As shown in Fig. 6c, the treatment with ATP (5 mM) induced a clear increase in annexin V-positive population
$(32.9 \pm 7.3 \%)$, and the selective P2X7R antagonist A740003 $(10 \mu \mathrm{M})$ significantly reduced the annexin Vpositive population in $32.8 \%(10.8 \pm 2.95 \%)$ (Fig. 6d). The irradiation (2 Gy) also caused an increase in the annexin V-positive population (21.7 $\pm 1.4 \%$ ) (Fig. 6e), and A740003 was able to partially reverse this parameter in $50.2 \%(10.9 \pm$ $0.75 \%$ ) (Fig. 6f).

In order to determine if irradiation might turn M059J cells more sensitive to ATP-induced cell death, as irradiation increase P2X7R expression, and also to confirm whether the receptor is still functional in this cell line after irradiation at 2 Gy, we irradiated these cells and after we treated them with ATP $(5 \mathrm{mM})$ or with A740003 $(10 \mu \mathrm{M})$ plus ATP $(5 \mathrm{mM})$. As shown in Fig. $6 \mathrm{~g}$, the treatment with ATP after irradiation revealed that annexin $\mathrm{V}$-positive population increased $(48.0 \pm 7.0 \%)$ when compared to irradiation or ATP treatment only, showing that cells become more sensitive to ATP and P2X7R is still functional after irradiation. Figure 6 h shows that A740003 was able to significantly 


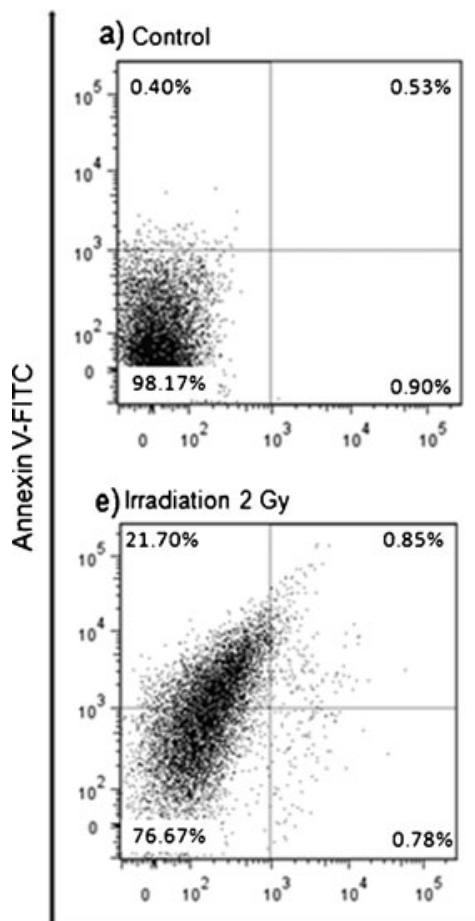

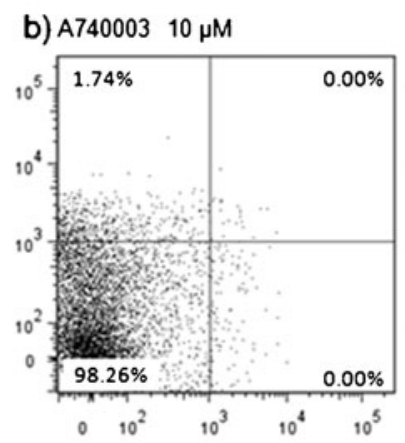

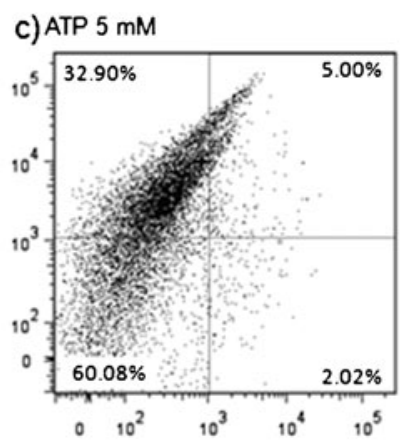

d) A740003 + ATP

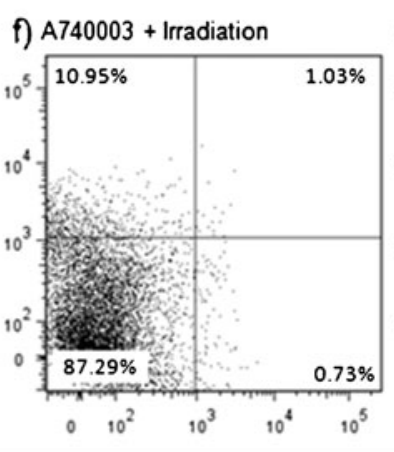

g) Irradiation + ATP

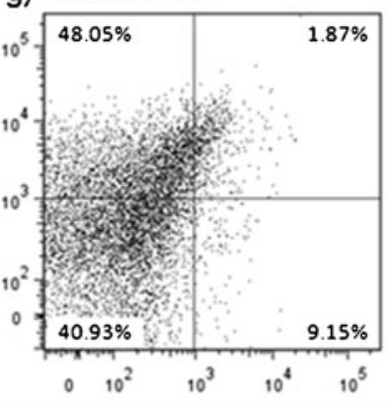

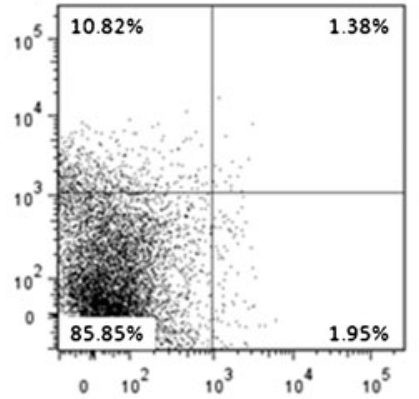

h) Irradiation + A740003 + ATP

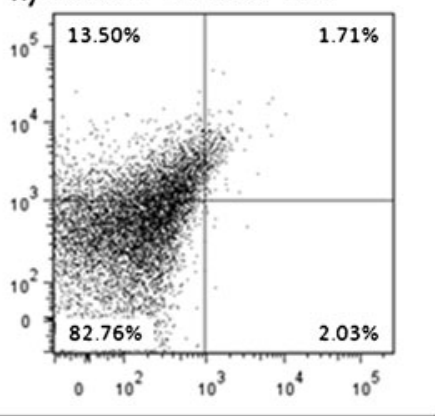

Propidium lodite $(\mathrm{PI})$

Fig. 6 Dot plot with percentage of Annexin V/PI positive M059J cells-24 h after treatment. Each sample has 50,000 cells. Data shown is representative of at least two independent experiments

reduce to $13.5 \pm 1.5 \%$ the effect of irradiation plus ATP $(48.0 \pm 7.0 \%)$, confirming that treatments effect are via P2X7R.

\section{Discussion}

The resistance of glioma cells to the effects of irradiation limits the success of the treatment [3] and identification of molecular mechanisms underlying glioma radioresistance is essential for development of combination therapies against this lethal pathology [10]. In the present study, we show that radioresistant U-138 MG and U-251 MG human glioma cells are also resistant to death caused by the P2X7R agonists ATP and BzATP (Figs. 1a-b and 2a-b). On the other hand, the radiosensitive M059J human glioma cell was found to be responsive to death provoked by ATP via P2X7R (Figs. 1c, 2c, and 6c). Our data establish a possible relationship between human glioma cells radiosensitivity and P2X7R activation.

The P2X7R is upregulated after acute brain injury [24], as irradiation. Herein, we found that the P2X7R expression in M059J cells was significantly higher than in radioresistant (Fig. 3a) lineages, and it is increased when this cell line was irradiated (Fig. 3b), leading us to believe that the activation of P2X7R induces, in part, to an inflammatory mechanism related to irradiation-induced cell death in radiosensitive lineages.

A study of Wei et al. [6] showed that P2X7R mRNA and protein present in unstimulated $\mathrm{C} 6$ rat glioma cells were upregulated by cell exposure to the P2X7R agonist BzATP. Even though, all three lineages studied here presented similar P2X7R protein levels (Fig. 4), and after irradiation (2 Gy), the radioresistant lineages (U-138 MG and U-251 MG) did not have their P2X7R protein levels increased, as expected after an injury [24]. Moreover, the P2X7R is unique in its ability to produce a large transmembrane pore upon intense stimulation [5]. Herein, we have shown that P2X7R pore is significantly more functional on M059J cell line when compared to U-138 MG and U-251 MG (Fig. 5a), related to its ATP-P2X7R sensitivity. Furthermore, M059J lineage was able to uptake more ethidium bromide than the other lineages irradiated (Fig. 5b). A possible explanation to ATP-P2X7R-resistance by U-138 MG and U-251 MG is provided herein: both U-138 MG and U-251-MG cell lines display significantly less $\mathrm{P} 2 \mathrm{X} 7 \mathrm{R}$ expression in relation to M059J cells (Fig. 3a). In fact, Tamajusuku et al. [2] have shown a positive correlation between ATP-induced cell death and the increase in P2X7R expression. The lack of P2X7R functionality on U-138 MG and U-251 MG glioma cells and reduced apoptosis can also be due to a mutation in the P2X7R protein, which detain their traffic to the plasma membrane [25]. This mutation does not prevent their detection with the 
antibody anti-P2X7R. As we have shown, P2X7R protein is present in these human glioma cell lines (Fig. $4 \mathrm{a}-\mathrm{b}$ ). Another point to consider is that pore formation requires accessory proteins for its activity, like pannexin [26]; thus, the expression of these proteins may also be deficient in the human glioma cells insensitive to extracellular ATP.

The death stimulated by ATP via P2X7R on M059J human glioma cell line has apoptotic features (Fig. 6c). Several studies have shown that cell death induced by activation of P2X7R is strongly dependent on the cell type [2], and the idea of a cell-membrane receptor linked to apoptosis is an attractive target for cancer therapy [27].

The cell death induced by ionizing irradiation, in general, is considered to be apoptotic [3], as we demonstrated in our study (Fig. 6e). Irradiation induces DNA doublestrand breaks (DSB), which are the most lethal form of damage to DNA. In mammals, DNA DSB is generally repaired via nonhomologous end joining, in which DNA-dependent protein kinase (DNA-PK) plays a key role [3]. It is already known that M059J cell line lack DNA-PK and is sensitive to irradiation $[3,11,12]$. In our paper, we propose an additional radiosensitization mechanism, in which $\mathrm{P} 2 \mathrm{X} 7 \mathrm{R}$ activation is implicated, via apoptosis induction. Accordingly, the pharmacological inhibition of P2X7R by its selective antagonist A740003 elicited a significant decrease of irradiationinduced death (Fig. 6f), even if stimulated with more ATP after irradiation (Fig. 6h).

Recently, Ohshima et al. [8] showed that $\gamma$-irradiation induces P2X7R-dependent ATP release from B16 melanoma cells and Wilhelm et al. [28] observed increased ATP concentrations after total body irradiation. The treatment with ATP $(5 \mathrm{mM})$ after irradiation induces more cell death of the ATP-sensitive cells (Fig. 6g), demonstrating that cells really become more sensitive to ATP after irradiation, probably because irradiation induce ATP release $[8,24]$ and increased P2X7R expression (Fig. 3b). We surmise that $\mathrm{P} 2 \mathrm{X} 7 \mathrm{R}$ is partially related to irradiation-induced cell death.

A multicentric study showed that patients that have gliomas with high P2X7R expression present longer survival, when compared to patients with gliomas expressing lower P2X7R levels [29]. Therefore, recovery strategies and/or expression and functional induction of P2X7R, which induces cell death in gliomas, warrants further investigation, since this receptor may be associated (or discarded) in the gene therapy with other anti-tumor genes.

In conclusion, we have shown for the first time that radioresistant glioma cells display less P2X7R mRNA and protein expression and reduced pore uptake capacity in comparison to a radiosensitive cell line, and that P2X7R activation increased cell death in the radiosensitive human glioma cell line. Our results provide convincing evidence on the possible involvement of $\mathrm{P} 2 \mathrm{X} 7$ receptor in glioma radiosensitivity. Understanding the roles of P2X7R in glioma cells may lead to a rationale testing of novel therapeutic strategies to inhibit tumor growth.

Acknowledgments This work was supported by Fundação de Amparo à Pesquisa do Estado do Rio Grande do Sul (FAPERGS) [Proc. 1016960], Coordenação de Aperfeiçoamento de Pessoal de Nível Superior (CAPES) and Financiadora de Estudos e Projetos (FINEP) [(PUCRSINFRA) \# 01.11.0014-00]. We thank for Dr. Carlos Henrique Barrios for the gift of the cell line, Dr. Robson Coutinho-Silva for the gift of compounds and Julia Cisilotto for help with the cell counting.

\section{References}

1. Meijer DH, Maguire CA, LeRoy SG, Sena-Esteves M (2009) Controlling brain tumor growth by intraventricular administration of an AAV vector encoding IFN-beta. Cancer Gene Ther 16 (8):664-671. doi:10.1038/cgt.2009.8

2. Tamajusuku AS, Villodre ES, Paulus R, Coutinho-Silva R, Battasstini AM, Wink MR, Lenz G (2010) Characterization of ATP-induced cell death in the GL261 mouse glioma. J Cell Biochem 109(5):983-991. doi: $10.1002 / j \mathrm{jcb} .22478$

3. Daido S, Yamamoto A, Fujiwara K, Sawaya R, Kondo S, Kondo Y (2005) Inhibition of the DNA-dependent protein kinase catalytic subunit radiosensitizes malignant glioma cells by inducing autophagy. Cancer Res 65(10):4368-4375. doi:10.1158/0008-5472. CAN-04-4202

4. Sun SH (2010) Roles of P2X7 receptor in glial and neuroblastoma cells: the therapeutic potential of $\mathrm{P} 2 \mathrm{X} 7$ receptor antagonists. Mol Neurobiol 41(2-3):351-355. doi:10.1007/s12035-010-8120-x

5. Verkhratsky A, Krishtal OA, Burnstock G (2009) Purinoceptors on neuroglia. Mol Neurobiol 39(3):190-208. doi:10.1007/s12035009-8063-2

6. Wei W, Ryu JK, Choi HB, McLarnon JG (2008) Expression and function of the P2X(7) receptor in rat C6 glioma cells. Cancer Lett 260(1-2):79-87. doi:10.1016/j.canlet.2007.10.025

7. Morrone FB, Horn AP, Stella J, Spiller F, Sarkis JJ, Salbego CG, Lenz G, Battastini AM (2005) Increased resistance of glioma cell lines to extracellular ATP cytotoxicity. J Neurooncol 71(2):135140. doi:10.1007/s11060-004-1383-1

8. Ohshima Y, Tsukimoto M, Takenouchi T, Harada H, Suzuki A, Sato M, Kitani H, Kojima S (2010) gamma-Irradiation induces P2X(7) receptor-dependent ATP release from B16 melanoma cells. Biochim Biophys Acta 1800(1):40-46. doi:10.1016/ j.bbagen.2009.10.008

9. Zheng M, Morgan-Lappe SE, Yang J, Bockbrader KM, Pamarthy D, Thomas D, Fesik SW, Sun Y (2008) Growth inhibition and radiosensitization of glioblastoma and lung cancer cells by small interfering RNA silencing of tumor necrosis factor receptorassociated factor 2. Cancer Res 68(18):7570-7578. doi:10.1158/ 0008-5472.CAN-08-0632

10. McLaughlin N, Annabi B, Bouzeghrane M, Temme A, Bahary JP, Moumdjian R, Beliveau R (2006) The survivin-mediated radioresistant phenotype of glioblastomas is regulated by RhoA and inhibited by the green tea polyphenol (-)-epigallocatechin-3-gallate. Brain Res 1071(1):1-9. doi:10.1016/j.brainres.2005.10.009

11. Virsik-Kopp P, Rave-Frank M, Hofman-Huther H, Schmidberger $\mathrm{H}$ (2003) Role of DNA-PK in the process of aberration formation as studied in irradiated human glioblastoma cell lines M059K and M059J. Int J Radiat Biol 79(1):61-68

12. Hoppe BS, Jensen RB, Kirchgessner CU (2000) Complementation of the radiosensitive M059J cell line. Radiat Res 153(2):125-130

13. Riteau N, Gasse P, Fauconnier L, Gombault A, Couegnat M, Fick L, Kanellopoulos J, Quesniaux VF, Marchand-Adam S, Crestani 
B, Ryffel B, Couillin I (2010) Extracellular ATP is a danger signal activating P2X7 receptor in lung inflammation and fibrosis. Am J Respir Crit Care Med 182(6):774-783. doi:10.1164/rccm.2010030359OC

14. Pelegrin P, Surprenant A (2009) Dynamics of macrophage polarization reveal new mechanism to inhibit IL-1beta release through pyrophosphates. EMBO J 28(14):2114-2127. doi:10.1038/ emboj.2009.163

15. Lemaire I, Falzoni S, Zhang B, Pellegatti P, Di Virgilio F (2011) The P2X7 receptor and Pannexin-1 are both required for the promotion of multinucleated macrophages by the inflammatory cytokine GM-CSF. J Immunol 187(7):3878-3887. doi:10.4049/ jimmunol.1002780

16. Luheshi NM, Giles JA, Lopez-Castejon G, Brough D (2011) Sphingosine regulates the NLRP3-inflammasome and IL-1beta release from macrophages. Eur J Immunol. doi:10.1002/eji.201142079

17. Thomas LM, Salter RD (2010) Activation of macrophages by P2X7-induced microvesicles from myeloid cells is mediated by phospholipids and is partially dependent on TLR4. J Immunol 185 (6):3740-3749. doi:10.4049/jimmunol.1001231

18. Ulmann L, Hirbec H, Rassendren F (2010) P2X4 receptors mediate PGE2 release by tissue-resident macrophages and initiate inflammatory pain. EMBO J 29(14):2290-2300. doi:10.1038/ emboj.2010.126

19. Rho HW, Lee BC, Choi ES, Choi IJ, Lee YS, Goh SH (2010) Identification of valid reference genes for gene expression studies of human stomach cancer by reverse transcription-qPCR. BMC Cancer 10:240. doi:10.1186/1471-2407-10-240

20. Ben Yebdri F, Kukulski F, Tremblay A, Sevigny J (2009) Concomitant activation of $\mathrm{P} 2 \mathrm{Y}(2)$ and $\mathrm{P} 2 \mathrm{Y}(6)$ receptors on monocytes is required for TLR1/2-induced neutrophil migration by regulating IL-8 secretion. Eur J Immunol 39(10):2885-2894. doi:10.1002/ eji.200939347

21. Morrone FB, Jacques-Silva MC, Horn AP, Bernardi A, Schwartsmann G, Rodnight R, Lenz G (2003) Extracellular nucleotides and nucleosides induce proliferation and increase nucleoside transport in human glioma cell lines. J Neurooncol 64(3):211-218

22. Jacques-Silva MC, Bernardi A, Rodnight R, Lenz G (2004) ERK, PKC and PI3K/Akt pathways mediate extracellular ATP and adenosine-induced proliferation of U138-MG human glioma cell line. Oncology 67(5-6):450-459. doi:10.1159/000082930

23. Morrone FB, Oliveira DL, Gamermann P, Stella J, Wofchuk S, Wink MR, Meurer L, Edelweiss MI, Lenz G, Battastini AM (2006) In vivo glioblastoma growth is reduced by apyrase activity in a rat glioma model. BMC Cancer 6:226. doi:10.1186/1471-2407-6-226

24. Kim JE, Ryu HJ, Yeo SI, Kang TC (2010) P2X7 receptor regulates leukocyte infiltrations in rat frontoparietal cortex following status epilepticus. J Neuroinflammation 7:65. doi:10.1186/17422094-7-65

25. Smart ML, Gu B, Panchal RG, Wiley J, Cromer B, Williams DA, Petrou S (2003) P2X7 receptor cell surface expression and cytolytic pore formation are regulated by a distal C-terminal region. J Biol Chem 278(10):8853-8860. doi:10.1074/jbc. M211094200M211094200

26. Pelegrin P, Surprenant A (2006) Pannexin-1 mediates large pore formation and interleukin-1beta release by the ATP-gated P2X7 receptor. EMBO J 25(21):5071-5082. doi:10.1038/sj.emboj. 7601378

27. White N, Burnstock G (2006) P2 receptors and cancer. Trends Pharmacol Sci 27(4):211-217. doi:10.1016/j.tips.2006. 02.004

28. Wilhelm K, Ganesan J, Muller T, Durr C, Grimm M, Beilhack A, Krempl CD, Sorichter S, Gerlach UV, Juttner E, Zerweck A, Gartner F, Pellegatti P, Di Virgilio F, Ferrari D, Kambham N, Fisch P, Finke J, Idzko M, Zeiser R (2010) Graft-versus-host disease is enhanced by extracellular ATP activating P2X7R. Nat Med 16 (12):1434-1438. doi:10.1038/nm.2242

29. (2008) Comprehensive genomic characterization defines human glioblastoma genes and core pathways. Nature 455(7216):10611068. doi: $10.1038 /$ nature 07385 